\title{
MOLECULAR CHARACTERIZATION OF MYCOPLASMA CONTAMINATING TISSUE CULTURES
}

\author{
DINA, Y.H. ELSHAFEY ${ }^{*}$; ABO-SHAMA, U.H. ${ }^{* *}$ and SAAD, A.A ${ }^{* * *}$ \\ * Department of Mycoplasma Research. \\ ** Department of Microbiology, Faculty of Veterinary Medicine, Sohag University. \\ **** Department of Virology Research- Animal Health Research Institute.
}

Email: usama.shama@gmail.com

Assiut University web-site: www.aun.edu.eg

\section{ABSTRACT}

Received at: $30 / 9 / 2015$

One of the main problems in cell culture unit is mycoplasma contamination. It can extensively affect cell physiology and metabolism. As the applications of cell

Accepted: 18/10/2015 culture increase in research, industrial production, cell therapy and its importance for diagnostic routine work in selected labs, so more concerns about mycoplasma contamination will arise. In our study, a total of 50 cell cultures from Animal Health Research Institute, Dokki, Giza., VACSERA and Veterinary Serum \& Vaccine institute Abbasia were monitored for mycoplasma using culture and PCR methodology. The contamination was detected in the cell culture collected from all laboratories. Mycoplasmas were detected by culture in 29/50 (58\%) of the cell culture samples which subsequently identified with PCR using Mycoplasma group specific primer detecting all species of mycoplasma which gave bands at $280 \mathrm{bp}$ in all positive culture samples, the most frequent species was $M$. arginini (30\%), followed by $M$. orale (28\%). MDBK were positive only for $M$. arginini which gave band at $326 \mathrm{bp}$, while VERO and BHK cells were infected only with M. orale which gave bands at $87 \mathrm{bp}$. Awareness about the sources of mycoplasma and pursuing aseptic techniques in cell culture unit along with reliable detection methods of mycoplasma contamination can provide an appropriate situation to prevent mycoplasma contamination in cell culture.

Keywords: Mycoplasma, Tissue Culture, contamination, PCR.

\section{INTRODUCTION}

Mycoplasma is the smallest free-living organisms that, unlike other bacteria, lack a cell wall. The outer layer is instead, a three layered membrane containing sterols. Diameters of these organisms may range from $0.2-0.3 \mu \mathrm{m}$ and, due to their plasticity, are able to pass through the pores of a 0.2 micron filter with applied pressure. Because the morphology of Mycoplasma is pleomorphic, they occur as two different structural forms during a life cycle: coccidian, a spherical or spheroidal shape, and filamentous, resembling rods. (Davis, 1994).

Each batch of live viral vaccine, each lot of master seed virus (MSV), each lot of primary and master cell stock (MCS), and all ingredients of animal origin not steam sterilized should be tested for the absence of mycoplasmas. Solid and liquid media that will support the growth of small numbers of tested organisms such as typical contaminating organisms Acholeplasma laidlawii, Mycoplasma arginini, $M$. fermentans, M. hyorhinis, M. orale, and M. synoviae should be used. The nutritive properties of the solid medium should be such that no fewer than $100 \mathrm{CFU}$ should occur with each tested organism when approximately 100-200 CFU are inoculated per plate. An appropriate colour change should occur in the liquid media when approximately 20-40 CFU of each tested organism are inoculated. The ability of the culture media to support growth in the presence of product should be validated for each product to be tested, and for each new batch or lot of culture media. (OIE Terrestrial Manual, 2012).

The field of tissue culture has developed very rapidly during recent years and tissue culture methodology has become a useful research tool in many branches of science. Animal tissue culture is concerned with the study of cells, tissues and organs explanted from animals and maintained or grown in vitro for more than 24 hours. Dependent upon whether cells, tissues or organs are to be maintained or grown, two methodological approaches have been developed in the field of tissue culture, cell culture and tissue or organ Culture. 
The application of cells in research laboratories (Nikfarjam et al., 1999; Isaian et al., 2003), regenerative medicine and biotechnological productions is growing extensively. Cells are used in wide-ranging activities from studies on cell proliferation to the production of biologically active substances. Due to restrictions on the use of laboratory animals by animal protection laws, the use of cell cultures will continue to increase in the future.

The importance of viral isolation as a diagnostic method still remains necessary because it is the only technique capable of providing a viable isolate that can be used for further characterization, such as with phenotypic antiviral susceptibility testing. Because no one cell culture type can support the growth of all medically relevant viruses, virology laboratories must maintain several different cell culture types. Barth and Melvin (2000).

In order to achieve reproducible results from cells, good cell culture conditions are vital. Despite the importance of bacterial and fungal contaminations in cell culture, they are not such a serious problem because they are usually obvious and easily detected. The most serious problem is mycoplasma contamination since these microorganisms are subtle (Hay,1986 and Harlin and Gajewski, 2008).

Mycoplasma contamination of cell cultures is a serious problem across the world because of the infection of cell cultures with mycoplasma can have different cytogenetic effects (Rottem and Barile, 1993). Mycoplasmas usually adhere to cells but, depending on the species, may fuse with the host cell or even invade it (Balish et al., 2002; Dimitrov, 1993 and Lo et al., 1993). These bacteria deplete the nutrients of cell cultures and interfere with the response of these cells when challenged experimentally (Miyazaki et al., 1990). Interruption of cell metabolism (Pollack et al., 1997), modulation of the immune response (Chambaud et al., 1999 and D'Orazio et al., 1996), modification of cellular morphology, interference with viral replication, chromosome modifications, or cell transformation may occur (Razin et al., 1998). The identification of these phenomena in accidental or experimental infections may contribute to the understanding of the relationship between mycoplasmas and the host cell (Rottem, 2003).

This distress contamination effects on eukaryotic cells represented in two significant problems to the culture of mammalian cells used for research as they can alter every cellular parameter leading to unreliable experiment results and potentially unsafe biological products (vaccines), first is Mycoplasma contaminate cell lines will produce much poorer yield of final cell numbers as they do not grow as high cell density as normal cells. Freshney (1994).

Second Mycoplasma also cannot detect by visual inspection using a normal light microscope and thus can remain unnoticed in cellular cultures for long period of time because mycoplasma are the smallest organism their genome size range from 0.6-1.3 mega base size characterized by lacking cell wall that are capable of self-replication and cause various disease in human and animals and plants. Razin (1996).

There are Different sources for the spreading of mycoplasma in the laboratory such as, a laminar flow hood during a routine subculturing procedure, Media, sera or reagents contaminated with mycoplasma, Nonsterile supplies, media and solutions, laboratory personnel, incubators, improper sealing of culture dishes. (Barile, 1973; McGarrity, 1976; PolakVogelzang et al., 1990 and Hay, 1991).

Robinson and Wichelhausen (1956) reported the first isolation of mycoplasma from a cell culture. Since then, mycoplasma had become recognized as a major culture contaminant. Published mycoplasma test results for cell lines during this time demonstrated rates of mycoplasma contamination between $57 \%$ to 92\% (Barile, 1973).

There are currently more than 183 species in 8 genera, many of which are pathogenic (Manual of Clinical Microbiology, 2003). The vast majority of cell culture contaminants belong to only 6 species primarily of human, bovine or porcine origin. Of these six species, $M$. orale and $M$. hyorhinis are the most common historically, accounting for over $50 \%$ of all mycoplasma contaminated cultures (McGarrity et al., 1979 and Barile et al., 1973).

As mycoplasma species grow extremely slow in tissue culture medium and do not destroy the cell lines, they can persist in cell cultures for an indefinite time without being noticed. Therefore, fast and reliable methods are required to detect mycoplasma contamination. Out of a vast array of techniques toward the detection of mycoplasma contamination of cell cultures, polymerase chain reaction (PCR)- based detection methods have become more popular, as they are not only highly sensitive and specific, but also simple, rapid, efficient, and cost effective (Drexler and Uphoff, 2002 and Kalhor et al., 2014).

The purpose of the present study was to introduce molecular characterization for mycoplasma species contaminated tissue culture as well as awareness about the sources of mycoplasma and pursuing aseptic techniques in cell culture unit along with reliable detection methods of mycoplasma contamination to provide an appropriate situation to prevent mycoplasma contamination in cell culture.

\section{MATERIAL and METHODS}

1- Samples: A total of 50 cell culture of animal origin samples were studied, including 23 Madin Darby Bovine Kidney (MDBK) Cells samples, 13 Baby Hamster Kidney (BHK) Cells samples, 13 
Green Monkey Kidney Cells (VERO) and one primary cell culture sample, these cell cultures were tested for potential mycoplasma contamination These cell lines were supplied from three sources:-

1- Tissue Culture Unit, Virology Department, Animal Health Research Institute, Dokki, Giza.

2- The Holding Company for Biological Products and Vaccines (VACSERA) Dokki, Giza.

3- Veterinary Serum and Vaccine institute AbbasiaCairo.

These cell monolayer's were propagated using Eagle's MEM with Earl's salts or with Hanks salts and $10 \%$ sterile newborn calf serum or $10 \%$ fetal calf serum. They distributed in $75 \mathrm{ml}$ sterile tissue culture flasks.

2- Media used for propagation of tissue cultures: 2.1-Newborn Calf Serum: Supplied by GIBCONewzeland (STERILE.A), Invitrogen Corporation, $\left(500 \mathrm{ml} /\right.$ Bottle), Stored at $-20{ }^{\circ} \mathrm{C}$.

2.2- Fetal Calf Serum: Supplied by Biowest- South America, (Vol.: $100 \mathrm{ML}$ ), Stored at $-20^{\circ} \mathrm{C}$.

Fetal and newborn calf sera were essential for preparation of all types of media, as well as considered one of the potential source for mycoplasma contamination of T.C.

\section{3- Minimum Essential Medium (Eagle's):}

Supplied by Sigma, USA with Hank's salt's and L.glutamine and without Sod. Bicarbonates, kept at 2 $-8^{\circ} \mathrm{C}$.

\section{4- Trypsin versine:}

\subsubsection{Trypsin:-}

Supplied by Sigma, (1:250).

\subsubsection{Versine:}

Supplied by WINLAB as power form.

2.5. Stock antibiotic solution: It was prepared as 1,000,000 IU Penicillin G Sodium, 1 g Streptomycin sulphate and $1 \mathrm{~g}$ mycostatin dissolved in $100 \mathrm{ml}$ HBSS. $1 \%$ of this solution was added to cell culture media and solutions to yield a final concentration of 100 IU of penicillin G. Sodium, $100 \mu \mathrm{g}$ of streptomycin sulphate and $100 \mu \mathrm{g}$ mycostatin $/ 1 \mathrm{ml}$.

2.6. Sodium bicarbonate solution (4.4\%): $4.4 \mathrm{~g}$ $\mathrm{NaHCO}_{3}$ dissolved in $100 \mathrm{ml}$ double distilled water and sterilized by autoclaving. It was used to adjust the required $\mathrm{pH}$ of the cell culture media and solutions.

\section{3- Media used for cultivation and isolation of Mycoplasma:}

3.1- Liquid and solid media for the isolation and propagation of mycoplasma were prepared as described by Sabry and Ahmed (1975).
3.2- Digitonin sensitivity test was done for the obtained isolates according to Erno and Stipkovits (1973).

3.3- Biochemical characterization was carried out by glucose fermentation and arginine deamination tests as described by Erno and Stipkovits (1973). Film and spot formation medium (Fabricant and Freundt, 1967).

4- Serological identification was conducted by growth inhibition test as described by (Clyde (1964). Standard antisera - locally prepared.

\section{5) Polymerase chain reaction:}

a) Preparation of samples for DNA extraction (Yleana et al., 1995): $5 \mathrm{ml}$ of a 24 hour broth cultures of isolates were centrifuged for 10 minutes at 12000 r.p.m. The pellet was washed twice in $1 \mathrm{ml}$ of phosphate buffered saline $\mathrm{pH} 7.2$ (PBS) and suspended in $50 \mu \mathrm{l}$ PBS. The cell suspension was heated directly at $100^{\circ} \mathrm{C}$ for $10 \mathrm{~min}$. in a heat block to break the cell membranes, and then cooled on ice for $5 \mathrm{~min}$. Finally, the cell suspension was centrifuged for $5 \mathrm{~min}$. and the supernate containing chromosomal DNA was collected and stored at $-20^{\circ} \mathrm{C}$ until used.

b) Oligonucleotide primers: The oligonucleotide primers used, including previously published primers, primer specificities, and expected amplicon lengths are shown in Tables 1 .

c) Procedure for DNA amplification: PCR amplification was performed in $50 \mu$ l reaction mixture consisting of $5 \mu \mathrm{l}$ of $50 \mathrm{ng} \mathrm{M}$. agalactiae genomic DNA, $10 \mu$ l of $10 \times$ Taq buffer $(10 \mathrm{mM}$ tris$\mathrm{HCl}$ [pH 8.8], $50 \mathrm{mM} \mathrm{KCl}), 1 \mu \mathrm{l}$ of $50 \mathrm{pM}$ of each primer, $1.5 \mathrm{mM} \mathrm{MgCl} 2,1 \mu \mathrm{l}$ of $2 \mathrm{U}$ of Taq thermos Table DNA polymerase, $1 \mu \mathrm{l}$ of $50 \mathrm{uM}$ of each dNTP, and $31 \mu 1$ of DNase- RNase- free, deionized water. DNA amplification was carried out in PTC-100 programmable thermal controller (MJ, Research Inc.). The thermal profiles were as follows: Denaturation at $94{ }^{\circ} \mathrm{C}$ for 45 seconds, primer annealing at $60^{\circ} \mathrm{C}$ for 1 min., and extension at $72^{\circ} \mathrm{C}$ for $2 \mathrm{~min}$. The amplifications were performed for 30 or 35 cycles with a final extension step at $72^{\circ} \mathrm{C}$ for $3 \mathrm{~min}$. After the reaction, the amplified DNA was electrophoresed on $1.5 \%$ agarose gel for $90 \mathrm{~min}$. at 100 volts, DNA Ladders: 100 bp (Pharmacia), Cat. No. 27-4001-01 and $50 \mathrm{bp}$ (Promega), Cat. no. G316A, USA were added then stained with ethidium bromide.

The resulting PCR product was separated by electrophoresis in $1.3 \%$ agarose gel, stained with ethidium bromide, visualized by UV transillumination and documented by photography. Image analysis was made by ImageQuantTLV2003.03 (Amersham Biosciences). The length of the amplification products were 87 to $1000 \mathrm{bp}$ depending on mycoplasma species (Table 1, Photo 8-11). 
Table 1: The used oligonucleotide primers, primer specificities, thermal cycle, expected amplicon lengths and the method reference.

\begin{tabular}{|c|c|c|c|c|c|c|}
\hline & $\begin{array}{c}\text { Mycoplasma } \\
\text { Species } \\
\end{array}$ & Forwarded primer & Reverse primer & $\begin{array}{l}\text { product } \\
\text { size (bp) }\end{array}$ & Thermal cycle & Reference \\
\hline 1 & $\begin{array}{l}\text { The mycoplasma } \\
\text { group-specific } \\
\text { primer set }\end{array}$ & $\begin{array}{c}\text { GPO-3 (5'-GGG } \\
\text { AGC AAA CAG } \\
\text { GAT TAG ATA CCC } \\
\text { T-3') }\end{array}$ & $\begin{array}{l}\text { MGSO (5'-TGC ACC } \\
\text { ATC TGT CAC TCT } \\
\text { GTT AAC CTC-3') }\end{array}$ & $280-b p$ & $\begin{array}{l}\text { The thermal profile consisted of } \\
40 \text { cycles of denaturation at } \\
94^{\circ} \mathrm{C} \text { for } 1 \text { min, primer } \\
\text { annealing at } 55^{\circ} \mathrm{C} \text { for } 1 \mathrm{~min} \text {, } \\
\text { and primer extension at } 72^{\circ} \mathrm{C} \\
\text { for } 2 \mathrm{~min} \text {. }\end{array}$ & $\begin{array}{l}\text { Van Kuppeveld } \\
\text { et al. (1994) }\end{array}$ \\
\hline 2 & $\begin{array}{l}\text { Sequence of } 16 \mathrm{~S} \\
\text { common gene for } \\
\text { Mycoplasma }\end{array}$ & $\begin{array}{c}\text { MunivF 5'- AGA } \\
\text { CTC CTA CGG } \\
\text { GAG GCA GCA -3' }\end{array}$ & $\begin{array}{c}\text { MunivR 5' ACT AGC } \\
\text { GAT TCC GAC TTC } \\
\text { ATG 3' }\end{array}$ & 1000-bp & $\begin{array}{l}\text { an intial denaturation step at } 94 \\
{ }^{\circ} \mathrm{C} \text { for } 5 \text { min., followed by } 35 \\
\text { cycles of denaturation at } 94{ }^{\circ} \mathrm{C} \\
\text { for } 1 \mathrm{~min} \text {, annealing at } 55{ }^{\circ} \mathrm{C} \\
\text { for } 1 \mathrm{~min} \text {., and extension at } 72 \\
{ }^{\circ} \mathrm{C} \text { for } 1.5 \text { min. A final } \\
\text { extension step at } 72{ }^{\circ} \mathrm{C} \text { for } 10 \\
\text { min }\end{array}$ & $\begin{array}{l}\text { Alberto et al. } \\
\quad(2006)\end{array}$ \\
\hline 3 & M. arginini & $\begin{array}{c}\text { TGA TCA TTA GTC } \\
\text { GGT GGA GAG } \\
\text { TTC }\end{array}$ & $\begin{array}{c}\text { TAT CTC TAG AGT } \\
\text { CCT CGA CAT GAC } \\
\text { TC }\end{array}$ & 326-bp & $\begin{array}{l}\text { initial denaturation at } 94 \text { C for } \\
3 \text { min, } 32 \text { cycles consisting of } \\
\text { denaturation at } 94{ }^{\circ} \mathrm{C} \text { for } 60 \mathrm{~s} \text {, } \\
\text { annealing at } 60{ }^{\circ} \mathrm{C} \text { for } 30 \mathrm{~s} \text { and } \\
\text { extension at } 72{ }^{\circ} \mathrm{C} \text { for } 60 \mathrm{~s} \text {, } \\
\text { followed by a final extension at } \\
72{ }^{\circ} \mathrm{C} \text { for } 5 \mathrm{~min} \text {. }\end{array}$ & $\begin{array}{l}\text { Vahid et al. } \\
\quad(2009)\end{array}$ \\
\hline 4 & M. orale & $\begin{array}{c}\text { GCA AAG CTA } \\
\text { TAG AGA TAT } \\
\text { AGT A }\end{array}$ & $\begin{array}{c}\text { GTC CTG CAA CGA } \\
\text { GCG CAA C }\end{array}$ & 87-bp & $\begin{array}{l}10 \text { min initial denaturation at } 95 \\
{ }^{\circ} \mathrm{C} \text {, followed by } 40 \text { cycles with } \\
15 \text { second at } 95{ }^{\circ} \mathrm{C} \mathrm{C} \text { and } 60 \\
\text { second at } 60^{\circ} \mathrm{C} \text {. }\end{array}$ & $\begin{array}{l}\text { Karin et al. } \\
\qquad(2014)\end{array}$ \\
\hline 5 & M. bovis & $\begin{array}{l}\text { MboF 5'-CCT TTT } \\
\text { AGA TTG GGA } \\
\text { TAGCGGATG-3' }\end{array}$ & $\begin{array}{c}\text { MboR 5- } \\
\text { CCGTCAAGGTAG } \\
\text { CGT CAT } \\
\text { TTCCTAC-3 }\end{array}$ & 360-bp & $\begin{array}{l}\text { Denaturation at } 94{ }^{\circ} \mathrm{C} \text { for } 45 \\
\text { seconds, primer annealing at } 60 \\
{ }^{\circ} \mathrm{C} \text { for } 1 \text { min., and extension at } \\
72{ }^{\circ} \mathrm{C} \text { for } 2 \text { min. the } \\
\text { amplifications were performed } \\
\text { for } 30 \text { or } 35 \text { cycles with a final } \\
\text { extension step at } 72{ }^{\circ} \mathrm{C} \text { for } 3 \\
\text { min. }\end{array}$ & $\begin{array}{c}\text { Chávez González } \\
\text { et al. }(1995)\end{array}$ \\
\hline
\end{tabular}

\section{RESULTS}

Mycoplasma contamination of cell cultures is a serious problem across the world because of the infection of cell cultures with mycoplasma can have different cytogenetic effects. The cell culture were examined for any changes or effects before uses, due to mycoplasma contamination many cytogenetic effects were detected, such as decrement of viability, detachment of adherent cells from the cell culture vessel surface (Photos 1\&2), inhibition of proliferation, cell growth interference, morphological changes (Photos $3 \& 4$ ). As well as severe cytopathic effects characterized by stunted, abnormal growth and rounded, degenerated cells (Photos 5\&6) were also detected.

A total of 50 cell culture samples were monitored for potential mycoplasma contamination using culture and PCR methodology. Mycoplasmas were detected by culture in 29/50 (58\%) of the cell culture samples. The cultured mycoplasmas presented "fried egg" colonies (Photo7), shifted the $\mathrm{pH}$ of the broth without turbidity and were subcultured after filtration. The mycoplasma reference strains grew on solid and liquid medium and were confirmed at the species level by PCR. Table 2, Photo 8-11 shows the general results obtained for the samples evaluated by culture and PCR.
Infected cultures were initially identified using common primers detecting all species of mycoplasma "MGSP" Mycoplasma group specific primer which provided by GPO and MGSO primers, as described in the Materials and Methods. Which gave bands at 280 bp (Photo 8) in 29/50 (58\%) of the cell culture samples.

As MDBK of bovine origin, so we make PCR for it with a common primers of bovine (16S rRNA) which give positive band at 1000 bp (Photo 9), so it may be M. bovis or M. arginini. Making PCR using M. bovis and $M$. arginini primers as described in the Materials and Methods gave a positive band only for $M$. arginini at $326 \mathrm{bp}$ (Photo 10), while negative for $M$. bovis with a frequenting of $15 / 50(30 \%)$ of the cell culture samples, which subsequently indicate that MDBK infected with only one Mycoplasma species M. arginini.

On the other hands, the infected VERO and BHK cells gave positive with a common primers "MGSP" but were negative with $16 S \mathrm{r} R N A$ primers of ruminant origin and positive for $M$. orale which gave bands at 87bp (Photo 11) in 14/50 (28\%) of the cell culture samples, indicating that VERO and BHK also infected only by $M$. orale. The most frequent mycoplasma species was $M$. arginini (30\%), followed by $M$. orale $(28 \%)$. 
Assiut Vet. Med. J. Vol. 61 No. 147 October 2015

Table 2: Results of isolation and biochemical of tissue culture samples.

\begin{tabular}{|c|c|c|c|c|c|c|}
\hline \multirow[t]{2}{*}{ Type } & \multicolumn{2}{|c|}{ Samples } & \multicolumn{2}{|c|}{ Positive samples by isolation } & \multirow[t]{2}{*}{ Digitonin test } & \multirow{2}{*}{$\begin{array}{c}\text { Glucose } \\
\text { fermentation }\end{array}$} \\
\hline & No & $\%$ & No & $\%$ & & \\
\hline MDBK & 23 & 46 & 15 & 30 & $+\mathrm{VE}$ & $-\mathrm{VE}$ \\
\hline BHK & 13 & 26 & 8 & 16 & $+\mathrm{VE}$ & $+\mathrm{VE}$ \\
\hline VERO & 13 & 26 & 6 & 12 & $+\mathrm{VE}$ & $+\mathrm{VE}$ \\
\hline $\begin{array}{c}\text { Original media } \\
\text { (primary) }\end{array}$ & 1 & 2 & 0 & 0 & $-\mathrm{VE}$ & $-\mathrm{VE}$ \\
\hline Total & 50 & & 29 & 58 & & \\
\hline
\end{tabular}

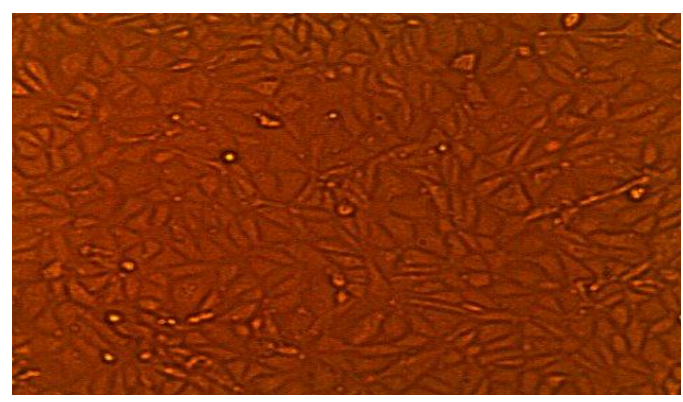

Photo 1: Normal MDBK Cell Line (Negative)

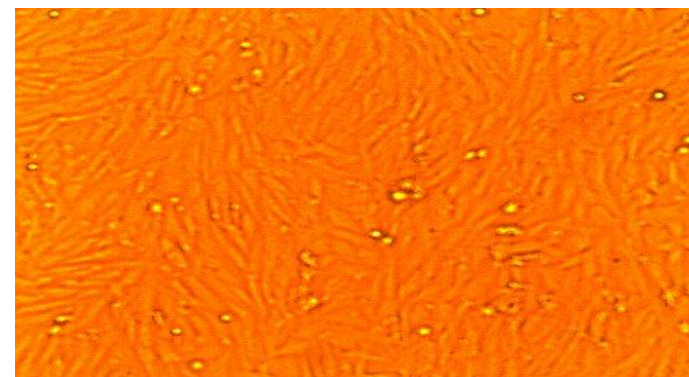

Photo 3: Normal BHK Cell Line (Negative)

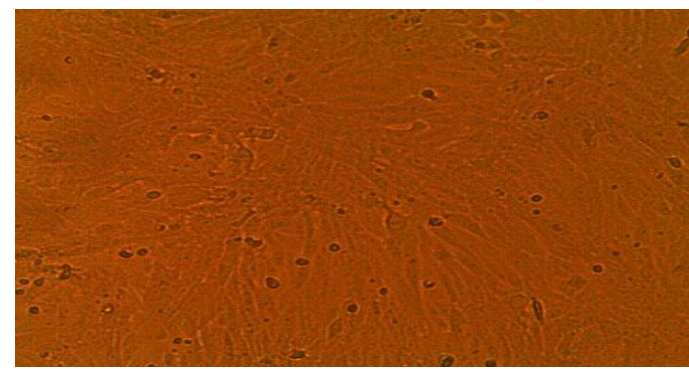

Photo 5: Normal Vero Cell Line (Negative)

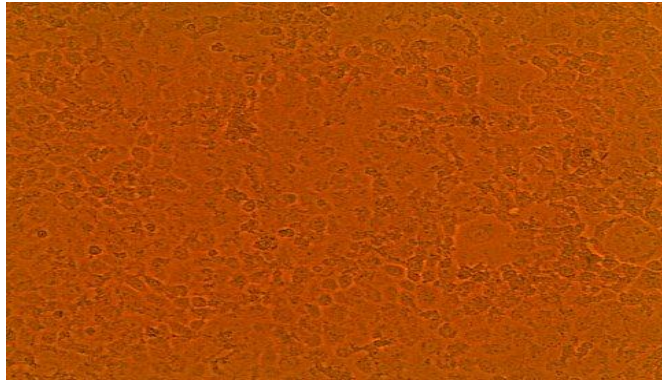

Photo 2: Vacculations and Detachment of MDBK cell layer

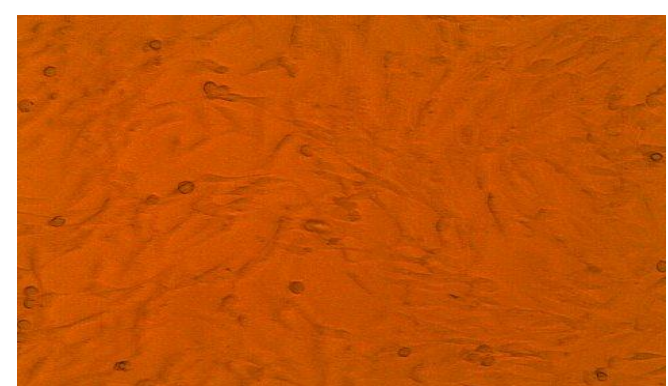

Photo 4: Deviation from normal fibroblastic morphology (24 hours).

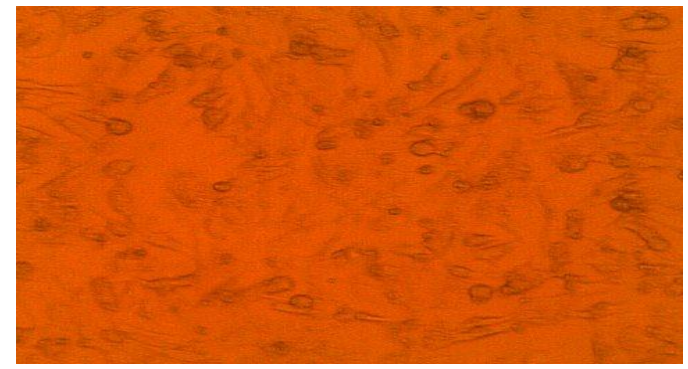

Photo 6: Loss of characteristic spindle shape of normal Vero cells, some rounding and finally, detachment (48 hours)

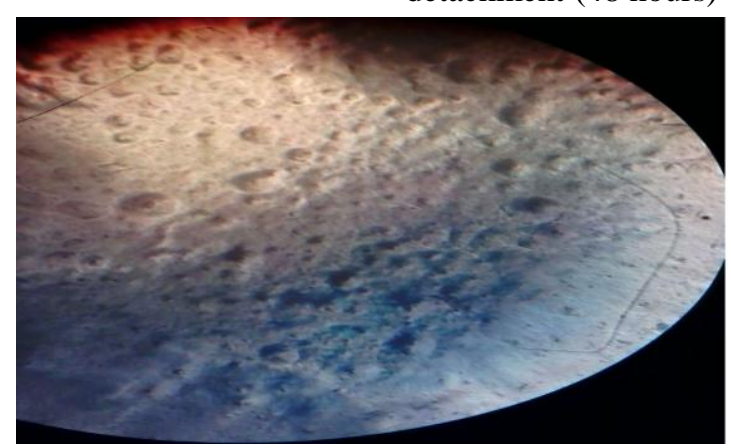

Photo 7: production of "fried egg" colonies on agar plates 


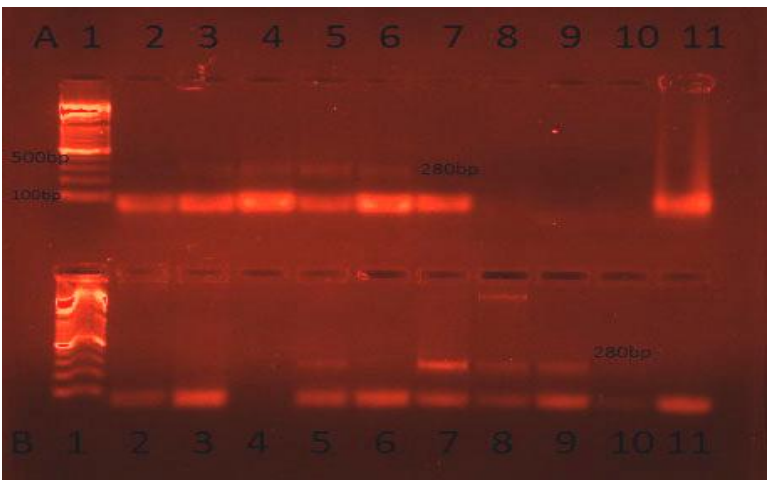

Photo 8: Above (A): lane 1: DNA 100bp marker, lane 2: negative control, lanes 3: positive control, lanes 4-7: positive samples at $280 \mathrm{bp}$ band, lanes $8,9 \& 11$ : negative samples. Down (B): lane 1: DNA 100bp Marker, lanes 5, 7, 8\&9: positive samples, lanes 2, 3, 4, 6, 10\&11: negative samples using the mycoplasma group-specific primer set, "MGSP".

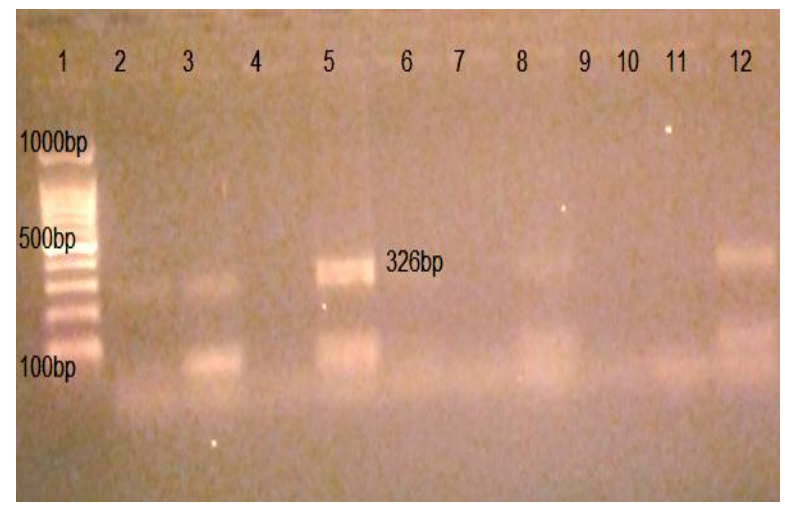

Photo 10: Lane 1: DNA 100bp Marker, lane4: negative control, lane 5: positive control M. arginine, lane 2,3,8\&12: positive sample, lanes $6,7,9,10 \& 11$ : negative samples using specific primer for $M$. arginine.

\section{DISCUSSION}

Mycoplasma is the most important and common source of cell culture infection, worldwide. Unlike bacterial and fungal infections which are readily identified by microscopic and visual inspections, mycoplasma infected cultures are hardly, if ever, detected by these routine inspections (Hay, 1986 and Harlin and Gajewski, 2008).

Accidental infection of cell cultures with mycoplasmas, especially when unnoticed, usually invalidates the results of biomedical researches. The cell cultures may not die, but remain altered and inadequate for experimentation for a long period of time (Fleckenstein and Drexler, 1996 and Drexler et al., 2002).

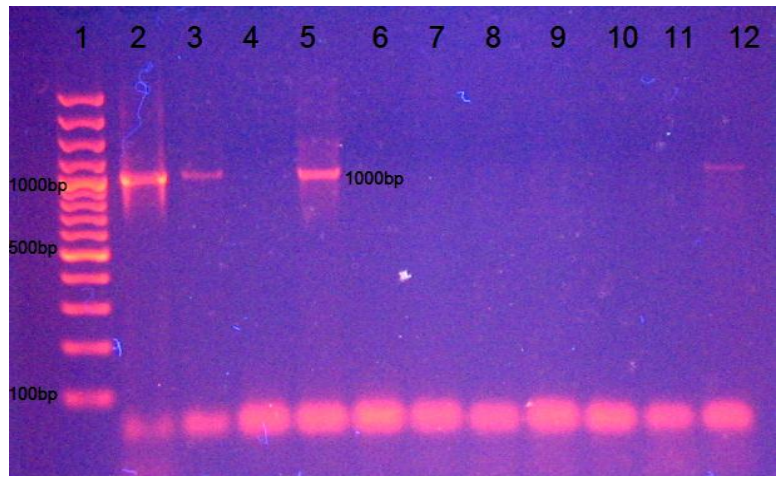

Photo 9: lane 1 DNA 100bp Marker, lane 2: positive control, lane 4: negative control, lane 3,5\&12: positive samples 1000bp band, lanes 6-11: negative samples by 16S rRNA common gene for Ruminant Mycoplasma.

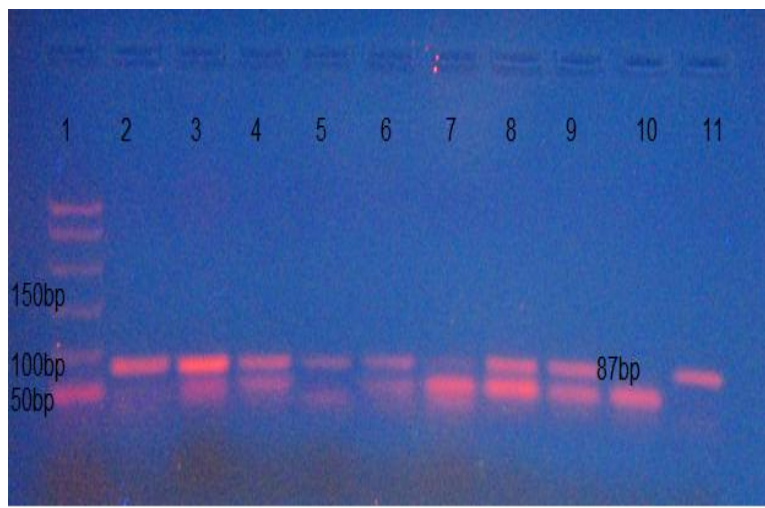

Photo 11: Lane 1: DNA 50bp Marker, lanes 2-9\&11: positive samples, lane 10: negative sample using specific primer for M. orale.

Mycoplasma-infected cell lines are themselves the single most important source for further spreading of the contamination. This is due to the high concentration of mycoplasmas in infected cultures, and the prolonged survival of dried mycoplasmas (Drexler and Uphoff, 2002). Operator-induced contamination is also a potential issue. Mycoplasmas spread by using laboratory equipment, media or reagents that have been contaminated (Drexler and Uphoff, 2002).

The behavior of mycoplasmas in cell culture is different; therefore, no consistent effects have ever been reported. The activity of arginine deiminase as well as uptake and depletion of the growth medium by mycoplasmas can inhibit the cell proliferation and induce apoptosis in cell lines. 
Reduction of arginine will result in abnormality of growth rate, decrement of viability, detachment of adherent cells from the cell culture vessel surface and granulation of cells. Moreover, chromosomal aberration will happen due to the lack of arginine as a major component of the histone in the nucleus (BenMenachem et al., 2001). Chromosome breakage, multiple translocation events, and numerical chromosome changes are other effects of different species of mycoplasma on cell cultures (McGarrity et al., 1984).

Generally, the side effects of mycoplasma contamination on cell cultures are:

1- Inhibition of proliferation, cell growth interference, morphological changes.

2- Severe cytopathic effects (CPE) characterized by stunted, abnormal growth and rounded, degenerated cells.

3- Amino and nucleic acid metabolism alterations, Increment in cell death.

4- Fragmentation of DNA, Chromosomal aberrations.

5- Change of gene expression patterns.

6- Morphological features of apoptosis (Sokolova et al., 1998).

The presence of mycoplasmas in cell cultures has also different side effects including loss of time, money, valuable cells and misleading publications, besides personal embarrassment and biosafety concerns (Nikfarjam and Farzaneh, 2011).

Several methods for the detection of mycoplasmas in cell cultures have been reported. The use of two methods has been the most recommended strategy to minimize false results. PCR in combination with culture is the most widely recommended procedure (Uphoff and Drexler, 2002).

The isolation of more than one mycoplasma species is time consuming even for a specialized laboratory. In this respect, PCR permits not only the diagnosis of mycoplasmas in cell cultures but also allows the determination of the distribution of species (Smith and Mowles, 1996). PCR permits the detection of femtogram amounts of mycoplasma DNA, corresponding to one bacterial cell. However, the sensitivity of specific PCR varies from species to species.

In a study by Timenetsky et al. (2006), M. orale, $M$. hyorhinis and $A$. laidlawii were found to be the most frequent species in cell cultures. While Uphoff and Drexler (2002) observed most of their cell lines were contaminated with M. fermentans, in our study, however, the most frequent species was $M$. arginini $(30 \%)$, followed by $M$. orale $(28 \%)$.
M. arginini has a wide host range as they have been isolated from mammals, birds and insects (Drexler and Uphoff, 2002). M. fermentans was believed to be associated with the development of AIDS in HIVpositive individuals in 1986 . However, the species is now considered to be a normal inhabitant of the human urogenital tract (Blanchard and Montagnier, 1994). Therefore, the increase in the frequency of $M$. fermentans in cell cultures can be explained by the growing use of human blood cells or tissues for primary culture (Timenetsky et al., 2006). The high incidence of the species $M$. arginini seems to be in direct correlation with the use of fetal or newborn bovine serum (Barile and Rottem, 1993). M. orale inhabits the human oropharynx and in addition to cell line cross-contamination may infect cell cultures through the aerosol generated by mouth pipetting (Razin et al., 1998), although this practice is now prohibited in most cell culture laboratories.

In summary, mycoplasmal contamination status of 50 cell lines including different mammalian cell types deposited in the different institutes in Egypt was obtained using PCR-based assay that allowed detection and identification of mycoplasmal contaminants in different types of cell lines with high sensitivity showed that $M$. arginin and $M$. orale were the most Mycoplasmal contaminant of cell culture. Due to the high Mycoplasmal contamination recovery $29 / 50(58 \%)$ in this study, which had personal embarrassment and biosafety concerns, regular microbiological examination for mycoplasma contaminating cell culture should be necessary methods for determination of quality and safety of tissue culture

\section{REFERENCES}

Alberto, A.; Addis, M.F.; Chessa, B.; Cubaddu, T.; Profiti, M.; Rosati, S.; Ruiu, A. and Pitau, M. (2006): Molecular and antigenic characterization of a Mycoplasma bovis strain causing an outbreak of infectious keratoconjunctivitis. J. Vet. Diagn. Invest. 18: 41-51.

Balish, M.F. and Krause, D.C. (2002): Cytoadherence and the cytoskeleton. In: Razin S, Herrmann R (Editors), Molecular biology and pathogenicity of mycoplasmas. New York: Kluwer Academic/Plenum Publishers;. p 491-518.

Barth Reller, L. and Melvin, P. Weinstein (2000): Section Editors Diagnostic Virology, Gregory A. Storch Departments of Pediatrics, Medicine, and Molecular Microbiology, Washington University School of Medicine, St. Louis, Missouri) Clinical Infectious Diseases; 31: 739-51 
Barile, M.F. (1973): Mycoplasmal flora of simians. J. Infect Dis. Mar; 127: Suppl: S17-20. J. Infect Dis. 1973 Mar; 127: Suppl: S17-20.

Barile, M.F. and Rottem, S. (1993): Mycoplasma in cell culture. In: Kahane I, Adoni A (eds) Rapid diagnosis of mycoplasmas. Plenum Press, New York, pp 155-193.

Barile, M.F.; Hopps, H.E.; Grabowski, M.W.; Riggs, D.B. and Del Giudice, R.A. (1973): The identification and sources of mycoplasmas isolated contaminated cell culture. Ann. NY. Acad Sci., 225: 251-264.

Barth, R.L. and Melvin, P.W. (2000): Section Editors Diagnostic Virology, Gregory A. Storch Departments of Pediatrics, Medicine, and Molecular Microbiology, Washington University School of Medicine, St. Louis, Missouri) Clinical Infectious Diseases; 31: 739-51.

Ben-Menachem, G.; Mousa, A.; Brenner, T.; Pinto, F.; Zahringer, U. and Rottem, S. (2001): Choline deficiency induced by Mycoplasma fermentans enhances apoptosis of rat astrocytes. FEMS Microbiol Lett., 201 (2): 157-162.

Blanchard, A. and Montagnier, L. (1994): AIDSassociated mycoplasma. Annu Rev Microbiol, 48: 687-712.

Chambaud, I.; Wroblewski, H. and Blanchard, A. (1999): Interactions between mycoplasma lipoproteins and the host immune system. Trends Microbiol; 7: 493-499.

Chávez González, Y.R.; Ros Bascuñana, C.; Bölske, G.; Mattsson, J.G.; Fernández Molina, C. and Johansson, K.E. (1995): In vitro amplification of the 16 sRNA genes from Mycoplasma bovis and Mycoplasma agalactiae by PCR. Vet. Microbiol., 47: 183-190.

Clyde, W.A. (1964): "Mycoplasma species identification based upon growth inhibition by specific antisera." J. Immunnol., 92: 958-965.

D’Orazio, J.A.; Cole, B.C. and Stein-Streilein, J. (1996): Mycoplasma arthritidis mitogen upregulates human NK cell activity. Infect Immun., 64: 441-447.

Dimitrov, D.S.; Franzoso, G.; Salman, M.; Blumenthal, R.; Tarshis, M. and Barile, M.F. (1993): Mycoplasma fermentans (incognitus strain) cells are able to fuse with Tlymphocytes. Clin Infect Dis; 17 (Suppl1): S305-S308.

Drexler, H.G and Uphoff, C.C. (2002): Mycoplasma contamination of cell cultures: incidence, sources, effects, detection, elimination, prevention. Cytotechnology, 39: 75-90.

Drexler, H.G.; Uphoff, C.C. and Dirks, W.G. (2002): Mix-ups and mycoplasma: the enemies within. Leuk Res., 26: 329-333.
Erno, H. and Stipkovits, L. (1973): Bovine mycoplasmas, cultural and biochemical studies. Acta. Vet. Scand., 14: 450-463.

Fabricant, J. and Freundt, E.A. (1967): Importance of extension and standardization of laboratory tests for the identification and classification of mycoplasma. Ann. N.Y. Acad. Sci., 143: 50-58.

Fleckenstein, E. and Drexler, H.G. (1996): Elimination of mycoplasma contamination in cell cultures. Biochemica, 1: 48-51.

Freshney, R. Ian. (1994): Culture of Animal Cells: A Manual of Basic Technique. $3^{\text {rd }}$ ed. WileyLiss: New York.

Harlin, H. and Gajewski, T.F. (2008): Diagnosis and treatment of mycoplasma-contaminated cell culture. Curr protoc Cytom., Appendix3, Appendix3c.

Hay, R.J. (1986): Animal Cell Culture: A practical approach. Freshney RI, editor .oxford: IRL Presi: $71-112$.

Hay, R.J. (1991): Operator-induced contamination in cell culture systems. Dev Biol Stand., 75: 193-204.

Isaian, A.; Pourpak, Z.; Nikfarjam, L. and Farhoodi, A. (2003): Comparison of two proliferation assays (MTT and LTT) in immunodeficient patients. Iran, Allergy Astma Immnol.: 2(2) 111-114.

Kalhor, N.; Fazaeli, H.; Tabatabaei Qomi, R.; Sheykh H.M. and Ghiasi, M. (2014): Detection of Mycoplasma Contamination in Adipose Tissue Derived Mesenchymal Stem Cells, SMU Medical Journal, 1(2).

Karin, J.; Gabi, R.; Andrea, H.; Karen, B.; Harald, K. and Peter, B. (2014): A Single-Tube RealTime PCR Assay for Mycoplasma Detection as a Routine Quality Control of Cell Therapeutics. Transfuse Med Hemother; 41: 83-89.

Lo, S.C.; Hayes, M.M.; Kotani, H.; Pierce, P.F.; Wear, D.J. and Newton, P.B. III, (1993): Adhesion onto and invasion into mammalian cells by Mycoplasma penetrans: a newly isolated mycoplasma from patients with AIDS. Mod Pathol; 6: 276-280.

Manual of Clinical Microbiology (2003): $8^{\text {th }}$ Edition. J Kerr. Murray P R, Baron E J, Jorgensen J H, et al, eds.

McGarrity, G.J. (1976): Spread and control of mycoplasmal infection of cell cultures. In Vitro., 12(9): 643 - 648.

McGarrity, G.J.; Vanaman, $V$. and Sarama, J. (1984): Cytogenetic effects on mycoplasmal infection of cell cultures: a review. In Vitro., 20: $1-18$

Miyazaki, K.; Takaku, H.; Umeda, M.; Fujita, T.; Huang, W.D. and Kimura, T. (1990): Potent growth inhibition of human tumor cells in culture by arginine deiminase purified from a 
culture medium of a Mycoplasma-infected cell line. Cancer Res; 50: 4522-4527.

OIE Terrestrial Manual (2012): Manual of Diagnostic Tests and Vaccines for Terrestrial Animals. 7th Edition, Volumes 1 and 2.

Polak-Vogelzang, A.A.; Angulo, A.F.; Brugman, J. and Reijgers, R. (1990): Survival of Mycoplasma hyorhinis in trypsin solutions. Biologicals., 18 (2): $97-101$.

Pollack, J.D.; Williams, M.V. and McElhaney, R.N. (1997): The comparative metabolism of the Mollicutes (Mycoplasmas): the utility for taxonomic classification and the relationship of putative gene annotation and phylogeny to enzymatic function in the smallest free-living cells. Crit. Rev. Microbiol; 23: 269-354.

Razin, S. (1996): Medical Microbiology: Chapter, 37Mycoplasmas. $4^{\text {th }}$ Ed. Ed. Kenneth J. Ryan. Stamford Appleton and Lange.

Razin, S.; Yogev, D. and Naot, Y. (1998): Molecular biology and pathogenicity of mycoplasmas. Microbiol Mol Biol Rev; 62: 1094-1156.

Robinson, L.B.; Wichelhausen, R.H. and Roizman, B. (1956): Contamination of human cell cultures by pleuropneumonia-like organisms. Science Vol. 124: 1147-1148.

Rottem, S. and Barile, M.F. (1993): Beware of mycoplasmas. Trends Biotechnol; 11: 143151.

Rottem S. (2003): Interaction of mycoplasmas with host cells. Physiol Rev; 83: 417-432.

Sabry, M.Z. and Ahmed, A.A. (1975): Evaluation of media and cultural procedure for the primary isolation of Mycoplasma from female genitalia of farm animals. J. Egypt. Vet. Med. Assoc., 35: $18-36$.

Smith, A. and Mowles, J. (1996): Prevention and control of mycoplasma infection of cell cultures. In: Tully JG, Razin S (Editors), Molecular and diagnostic procedures in mycoplasmology. San Diego: Academic Press; p 445-451.

Sokolova, I.A.; Vaughan, A.T. and Khodarev, N.N. (1998): Mycoplasma infection can sensitize host cells to apoptosis through contribution of apoptotic-like endonuclease(s). Immunol Cell Biol.; 76(6): 526-534

Timenetsky, J.; Santos, L. and Buzinhani, M. (2006): Detection of multiple mycoplasma infection in cell cultures by PCR. Braz, J. Med. Biol Res., 39: 907-914.

Uphoff, C.C. and Drexler, H.G. (2002): Comparative PCR analysis for detection of mycoplasma infections in continuous cell lines. In Vitro Cell Dev Bio Anim., 38: 79-85.

Vahid, M.K.; Mohammad, A.S.; Mohammad, R.A.; Morteza, S.M.; Shahram, A.; Susan, M.; Amir, A.; Mahmood, J.T. and Fazel, S. (2009): PCRbased detection and eradication of mycoplasmal infections from various mammalian cell lines: a local experience. Cytotechnology, 61: 117-124.

Van Kuppeveld, F.J.M.; Johansson, K.E.; Galama, J.M.D.; Kissing, J.; Bolske, G.; Van Der Logt, J.T.M. and Melchers, W. J.G. (1994): Detection of Mycoplasma Contamination in Cell Cultures by a Mycoplasma GroupSpecific PCR. Applied and Environmental Microbiology, 60(1): 149-152.

Yleana, R.; Chávez, G.; Ros Buscunana, C.; Bolske, G.; Mattsson, J.G.; Fernández Molina, C. and Johansson, K.E. (1995): In vitro amplification of the 16S rRNA genes from Mycoplasma bovis and Mycoplasma agalactiae by PCR. Vet. Microbiol., 47: 183-190.
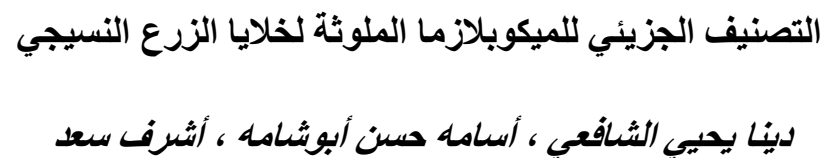

Email: usama.shama@gmail.com Assiut University web-site: www.aun.edu.eg

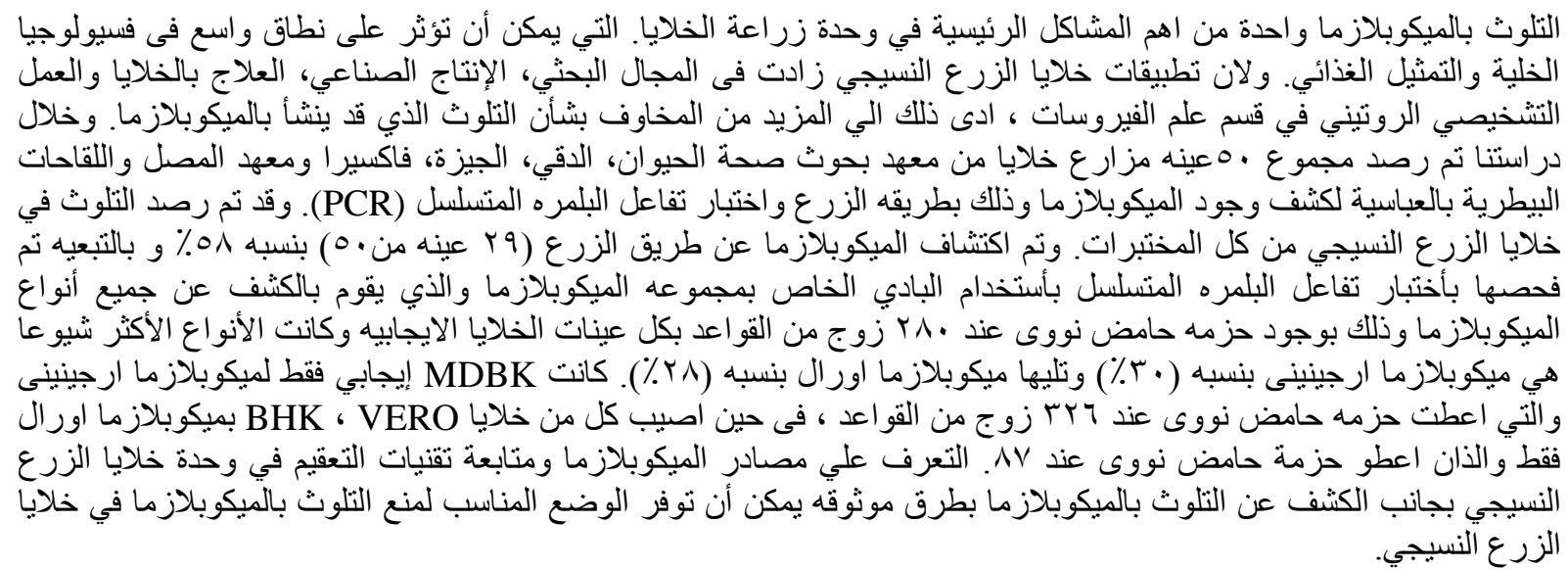

